This is a self-archived version of an original article. This version may differ from the original in pagination and typographic details.

Author(s): Saloviita, Timo

Title: Explaining classroom teachers' attitudes towards inclusive education

Year: 2019

Version: Accepted version (Final draft)

Copyright: @ 2019 NASEN

Rights: In Copyright

Rights url: http://rightsstatements.org/page//nC/1.0/?language=en

Please cite the original version:

Saloviita, T. (2019). Explaining classroom teachers' attitudes towards inclusive education.

Support for Learning, 34(4), 432-442. https://doi.org/10.1111/1467-9604.12277 


\section{Explaining classroom teachers' attitudes towards inclusive education}

\section{Timo Saloviita}

Department of Teacher Education, University of Jyvaskyla, Jyvaskyla, Finland

Corresponding author: Timo Saloviita, Department of Teacher Education, University of Jyvaskyla, PO Box 35, 40014 Jyväskylän yliopisto, Finland.

Phone: +358 408053373; Email: timo.saloviita@jyu.fi

http://orcid.org/0000-0001-6723-3675 


\section{Explaining classroom teachers' attitudes towards inclusive education}

Teacher attitudes have been identified as an important resource when striving towards inclusive education as defined in the Salamanca Statement (1994). This study surveyed some key factors associated with teacher attitudes towards inclusion. The participants were 1,456 classroom teachers in Finnish primary schools who were asked about their readiness to include in their classrooms a student with a specified special educational need (SEN). The results were reviewed in association with some background variables, including workload concerns, evaluation of professional skills and the opportunity to get extra support if needed. The results show that classroom teachers' positive attitudes towards inclusion were associated with their feeling that special classes represent an inappropriate placement for students with SEN, their belief in their ability to get outside support, their reliance on their own professional skills and their lower expectations regarding additional workload.

Key words: inclusive education; teacher attitudes; Finland; special education; workload 


\section{Explaining classroom teachers' attitudes towards inclusive education}

\section{Introduction}

Inclusive education became a common watchword after the 1994 UNESCO meeting in Salamanca and the publication of the conference document, 'The Salamanca Statement and Framework for Action on Special Needs Education' (UNESCO, 1994). The concept of 'inclusive education' had rarely been used before the conference, but afterwards the new pairing of words began to compete with 'special education' for dominance. While the old term, 'integration', did imply a moderate wish for the mainstream placement of students who were able to adapt to normal environments, the new phrase suggested a radical paradigm shift: the demands for change were now made upon school environments and no longer upon students. This actually meant the demolition of the traditional special-education system.

Teachers' reactions to the prospect of inclusion have not been very positive (Avramidis \& Norwich, 2002; de Boer, Pijl \& Minnaert, 2011; Scruggs \& Mastropieri, 1996). This is easy to understand, taking into account that separate special-education structures were very much the creation of the teaching profession itself. The reasons for teachers' negative attitudes have been widely studied, and the results show that they are only weakly associated with person-related variables such teachers' age, gender, experience, training or sentiments towards disabilities (Avramidis \& Norwich, 2002; de Boer, Pijl \& Minnaert, 2011; Scruggs \& Mastropieri, 1996). Instead, a teacher's professional role (Hernandez, Hueck \& Charley, 2016; Moberg, 2003) and the level of the student's disability (Avramidis \& Kalyva, 2007) have been the two factors most clearly associated with teachers' attitudes.

The explanation may lie in teachers' concerns over workloads. Special-education teachers are more positive towards inclusion than classroom teachers. This is easy to 
understand, taking into account that inclusive placements imply a higher probability of additional work for the latter. Students with more severe disabilities are less willingly included than students with mild disabilities, and they also cause more work for teachers. Workload concerns are, indeed, frequently stated as a challenge in inclusive education (Ahsan, Deppeler \& Sharma, 2013; Avramidis \& Norwich, 2002; Engelbrecht et al., 2013; Goodman \& Burton, 2010; Gunnpórsdóttir \& Jóhannesson, 2014; Yada \& Savolainen, 2017). The problem is also evident in the fact that a majority of teachers usually lament a lack of resources as an obstacle to inclusion (Avramidis, Bayliss \& Burden, 2000; Buell et al., 1999; Coutsocostas \& Alborz, 2010; Horne \& Timmons, 2009; Scruggs \& Mastropieri,1996; Subban \& Sharma, 2006). If the lack of adequate resources is real, it naturally endangers successful education.

Other findings further complicate the overall picture of teacher attitudes. First, a lack of resources seems credible in the context of developing countries (Srivastava, de Boer \& van Pijl, 2015), but the shortage of resources is equally lamented in prosperous states (Goodman \& Burton, 2010; Gunnpórsdóttir \& Jóhannesson, 2014). Second, even if several concerns about inclusion are commonly presented in survey studies, those concerns have explained very little of the variance in teachers' attitudes towards inclusion (Yada \& Savolainen, 2017). Nor has providing more resources always solved the problems. Sometimes, additional resources have had a minimal effect on teacher attitudes (Center \& Ward, 1987) or no effect at all (Chiner \& Cardona, 2013).

Perhaps the key to the problem can be found in the specific type of resources provided. While giving teachers more time, in-service training or material support may not make their attitudes more positive (Chiner \& Cardona, 2013), the provision of administrative support (Ahmmed, Sharma \& Deppeler, 2014; Larrivee \& Cook, 1979) 
and collaboration between teachers (Chiner \& Cardona, 2013; Minke et al.,1996) have increased teachers' positive attitudes towards inclusion.

\section{Aims of the study}

Based on the above considerations, the present study surveyed classroom teachers' attitudes towards inclusion by presenting them with five types of SEN students who differed from one another in their levels of disability. For each case, teachers were asked to evaluate whether they would be willing to accept the student into their classroom and whether the student would cause them extra work. The teachers were also asked whether they had adequate skills to teach the student and whether they believed that they could get the necessary support in their classroom if needed. Finally, they were asked whether they considered a special-education classroom to be the best place for the student. The teachers' responses are expected to shed light on the associations of some important factors that possibly influence teachers' attitudes towards inclusive education.

\section{Participants and data collection}

The participants were 1,456 classroom teachers in Finnish primary schools who worked in grades $1-6$. Of them, $77 \%(\mathrm{~N}=1124)$ were women and $22 \%(\mathrm{~N}=309)$ men. Their mean age was 46 years $(\mathrm{SD}=9.7)$, and $96 \%$ of them were qualified for their profession. Additional qualifications included some school subjects (29\%) and qualification as a resource-room teacher $(2 \%)$ or special-education class teacher $(2 \%)$. The gender distribution and number of qualified teachers corresponded to governmental data (Finnish National Agency for Education, 2016).

Preservice teachers $(\mathrm{N}=87)$ collected the data in 2018 as part of their university course on statistics. The teachers' email addresses were obtained from the schools' official websites. Each teacher in the sample was sent an email containing a link to the 
survey. The total number of emails sent was 25,678 , which covered about $66 \%$ of all primary school teachers in Finland (Kumpulainen, 2014). Schools that did not provide teachers' email addresses on their websites were not included in the sample. The sample did contain subject teachers and special-education teachers, but the present study concentrated only on classroom teachers. The return rate of the survey was $13.2 \%$. Because of the low return rate, the research task was modified to focus on the relationships between the variables rather than on the absolute distributions.

The ethical principles of National Advisory Board on Research Ethics in Finland (2009) were followed. The cover letter of the survey gave information on the aims of the study and emphasised that participation on it was voluntary and anonymous. Individual respondents, schools or municipalities could not be identified on the basis of data. The anonymity of data collection guaranteed full privacy for the participants on all levels.

\section{Variables and data analysis}

The questionnaire contained demographic variables and questions about the school. Five types of special-educational needs were selected for the inquiry. They were (1) learning disabilities (LDs), defined as students with a slow learning capacity in most school subjects, (2) severe cerebral palsy (CP), with a separate mention of difficulties in speech and motor skills, (3) attention deficit hyperactivity disorder (ADHD), (4) severe intellectual disability and (5) imperfect Finnish skills because of an immigration background.

Five statements were presented to be answered separately for each type of SEN. The response alternatives on a 5-point Likert scale ranged from 'strongly disagree' (scored 1) to 'strongly agree' (scored 5), with a neutral midpoint. The sum scores were calculated for each statement by summing the answers across the five types of SEN. 
The statements, with the reliability value for each five-item scale thus constructed, were as follows: (1) 'I am willing to accept in my classroom a student (with a specified SEN)' $(\alpha=0.80)$; (2) 'A student (with a specified SEN) causes extra work for the teacher' $(\alpha=0.81)$; (3) 'I believe I can get enough extra support if I have a student (with a specified SEN) in my classroom' ( $\alpha=0.78)$; (4) 'I have adequate skills to instruct the child (with a specified SEN)' $(\alpha=0.74)$; (5) 'A special-education classroom is the best place for a student (with a specified SEN)' $(\alpha=0.69)$. Three questions concerning inclusive education as a goal were also presented, with response alternatives similar with the statements above.

The data were calculated using the IBM SPPS program, version 24.0. The results are presented mainly as descriptive statistics. Some statistical significance tests are also used, supplemented by effect-size measures.

\section{Table 1 about here}

\section{Findings}

Corresponding with earlier studies in the field, the teachers' readiness to accept an SEN student in their classrooms was associated with the severity of the student's disability or the challenge presented by the student to classroom instruction (Table 1). The most essential findings were the relationships between the various types of SEN, as the absolute percentages may be distorted because of the low return rate. It is highly probable that the participants were selected by their higher interest in matters of inclusive education.

The acceptance of the student was not closely associated with the need for extra work. Students with severe disabilities were actually considered to cause less extra work for teachers than students with milder problems (Table 1). Students with milder 
problems possibly caused more concerns about extra work because the teachers did not believe they would get additional support in their classrooms in those cases (Table 1).

Teachers' expectations of extra work were high, indicating that they believed that inclusion causes additional work for teachers. The correlation coefficient between a student's acceptability and the expected extra work was not counted due to the high skewness of the variable of extra work (skewness $=4.29 ; \mathrm{SD}=0.044)$. Instead, the teachers who scored highest in the expectation of extra work $(\mathrm{N}=401)$ were compared with other teachers $(\mathrm{N}=1003)$. This comparison indicated that the teachers with the highest expectations of extra work due to inclusion also held more negative attitudes towards inclusion $(\mathrm{t}[670]=4.70 ; \mathrm{p}<0.000)$. The effect size was $\mathrm{d}=0.28$, indicating a small difference between the means.

Teacher recommendations for special classrooms were associated with the severity of the challenge presented by the student. An exception was the immigrant students. They were considered to cause much additional work, but they were still accepted in the mainstream classrooms. This was so even if the majority of the teachers believed that they lacked adequate professional skills for the instruction of immigrant students (Table 1).

The teachers' opinions regarding immigrant students seem to indicate that, if teachers believe that special classrooms are not the best place for a certain category of students, they are ready to accept those students in their own mainstream classrooms despite the teachers' lack of skills or the imposition of extra work. One might conclude that worries about extra work or inadequate skills are of only secondary importance, while the main factor is a teacher's perception of the 'right' place for each student. This conclusion is also supported by the finding that a teacher's willingness to accept a student with an SEN correlated strongly with her view that a special-education 
classroom was not the best place for the student $(r=-.506 ; \mathrm{p}<0.000)$. The attitude towards the appropriateness of special classrooms explained as much as $25 \%$ of the variance in the variable that measured the acceptability of the student. It may well be that teachers refer to workload problems or inadequate skills only to provide more weight to their opinion, which is actually based on deeper reasons.

Classroom teachers' willingness to accept SEN students into their classrooms correlated positively with the teachers' ability to get extra help in the classroom ( $\mathrm{r}=$ $0.200 ; \mathrm{p}>0.000)$ and especially with their belief in their skills to instruct SEN students $(\mathrm{r}=0.447 ; \mathrm{p}<0.000)$. The direction of causality, however, remains unclear, as one could argue for the existence of causality in both directions.

Class size did not explain teachers' attitudes towards inclusion $(r=0.023 ; \mathrm{p}=$ 0.395), even if limited time is frequently presented as a barrier to inclusion (Buell et al., 1999; Hadjikakou \& Mnasonos, 2012). When the class size was classified in four groups (fewer than 18 students, 18-20, 21-23, and more than 23), no linear association was found between the teacher's class size and her opinion on the acceptability of students with SEN in her classroom $(F[1,1386] 0.768 ; p=0.381)$.

Of the teachers, $66 \%$ believed that inclusive education was a goal in Finnish school law, while 5\% disagreed. Actually, inclusive education is not mentioned in Finnish school law and never has been. The principle guiding the physical placement of a student is 'the student's best interest and local circumstances' (Act on Basic Education, 1998/2010). It is possible that, because of these imprecise criteria, selfcontained special-education classrooms have freely emerged as a large sector in primary education (EADSNE, 2018; Statistics Finland, 2018). The teachers were probably mistaken because the concept of inclusion has been frequently used in the in-service training of the Finnish National Agency of Education since 2000. However, the 
meaning of the concept has widened from its original special-education context (Halinen \& Järvinen, 2008), which probably explains why the majority of respondents (61\%) also considered inclusion to be the official goal of their own schools. A small majority of teachers (59\%) knew that the principle of inclusive education was incorporated in the United Nations' Convention on the Rights of People with Disabilities (2006). A large minority, 41\%, was unaware of it, while only $3 \%$ disagreed.

A limitation of the present study is the low return rate. The analysis was adjusted to the possible bias so that relations between the variables, rather than absolute distributions, were emphasised. The reliability of the results was confirmed by their correspondence with findings from previous research. Additional confirmation was provided by the results of demographic variables. Female teachers were found to be more positive towards inclusion than male teachers $(\mathrm{t}[940]=2.70 ; \mathrm{p}=0.004)$ and younger teachers more positive than older ones $(r=-0.169 ; \mathrm{p}<0.000)$. These results are in harmony with the majority of previous studies (Avramidis \& Norwich, 2002; de Boer, Pij1 \& Minnaert, 2011; Scruggs \& Mastropieri, 1996).

The present study found that teachers' attitudes towards including an SEN student were strongly associated with the specific category of SEN. While this finding was not new, other variables included in the analysis indicate that teachers' usual explanations for their stance are not always supported by the data. It is recommended that future studies strive to avoid offering excessively superficial explanations for teacher attitudes towards inclusion. This study supported the notion that teachers' opinions concerning the 'right' place for a student was the key factor in their decision to accept or reject the child.

\section{References}


ACT ON BASIC EDUCATION (1998/2010) Perusopetuslaki. Finlex 628/1998.

AHMMED, M., SHARMA, U. and DEPPELER, J. (2014) Variables affecting teachers' intentions to include students with disabilities in regular primary schools in Bangladesh. Disability \& Society, 29, 2, 317-331.

AHSAN, M. T., DEPPELER, J. M., and SHARMA, U. 2013. Predicting preservice teachers' preparedness for inclusive education: Bangladeshi pre-service teachers' attitudes and perceived teaching-efficacy for inclusive education. Cambridge Journal of Education, 43, 517-535.

AVRAMIDIS, E., BAYLISS, P. and BURDEN, R. (2000) A survey into mainstream teachers' attitudes towards the inclusion of children with special educational needs in the ordinary school in one local education authority. Educational Psychology, 20, 2, 191-211.

AVRAMIDIS, E. and KALYVA, E. (2007) The influence of teaching experience and professional development on Greek teachers' attitudes towards inclusion. European Journal of Special Needs Education, 22, 4, 367-389.

AVRAMIDIS, E. and NORWICH, B. (2002) Teachers' attitudes towards integration/inclusion: a review of the literature. European Journal of Special Needs Education, 17, 2, 129-147.

BUELL, M. J., HALLAM, R., GAMEL-MCCORMICK, M. and SCHEER, S. (1999) A survey of general and special education teachers' perceptions and inservice needs concerning inclusion. International Journal of Disability, Development and Education, 46, 2, 143-156.

CENTER, Y. and WARD, J. (1987) Teachers' attitudes towards the integration of disabled children into regular schools. The Exceptional Child, 34, 1, 41-56. 
CHINER, E. and CARDONA, M. C. (2013) Inclusive education in Spain: how do skills, resources, and supports affect regular education teachers' perceptions of inclusion? International Journal of Inclusive Education, 17, 5, 526-541.

COUTSOCOSTAS, G. G. and ALBORZ, A. (2010) Greek mainstream secondary school teachers' perceptions of inclusive education and of having pupils with complex learning disabilities in the classroom/school. European Journal of Special Education, 25, 2, 149-164.

DE BOER, A., PIJL, S. J. and MINNAERT, A. (2011) Regular classroom schoolteachers' attitudes towards inclusive education: a review of the literature. International Journal of Inclusive Education, 15, 3, 331-353. doi:10.1080/13603110903030089.

ENGELBRECHT, P., SAVOLAINEN, H., NEL, M. and MALINEN, O.-P. (2013) How cultural histories shape South African and Finnish teachers' attitudes towards inclusive education: a comparative analysis. European Journal of Special Needs Education, 28, 3, 305-318.

\section{EUROPEAN AGENCY FOR SPECIAL NEEDS AND INCLUSIVE EDUCATION}

(EADSNE) (2018) (J. Ramberg, A. Lénárt and A. Watkins, eds.) European Agency Statistics on Inclusive Education: 2016 Dataset Cross-Country Report. Odense, Denmark: EADSNE.

FINNISH NATIONAL AGENCY FOR EDUCATION (2016) Opettajat ja rehtorit Suomessa 2016 [Teachers and principals in Finland in 2016]. Helsinki: Finnish National Agency for Education.

GOODMAN, R. L. and BURTON, D. M. (2010) The inclusion of students with BESD in mainstream schools: teachers' experiences of and recommendations for 
creating a successful inclusive environment. Emotional and Behavioural Difficulties, 15, 3, 223-237.

GUNNbÓRSDÓTTIR, H. and JÓHANNESSON, I. A. (2014) Additional workload or a part of the job? Icelandic teachers' discourse on inclusive education. International Journal of Inclusive Education, 18, 6, 580-600.

HADJIKAKOU, K. and MNASOS, M. 2012. Investigating the attitudes of head teachers of Cypriot primary schools towards inclusion. Journal of Research in Special Educational Needs, 12, 2, 66-81.

HALINEN, I. and JÄRVINEN, R. (2008) Towards inclusive education: the case of Finland. Prospects, 38, 1, 77-97.

HERNANDEZ, D. A., HUECK, S. and CHARLEY, C. (2016) General education and special education teachers' attitudes towards inclusion. Journal of the American Academy of Special Education Professionals, 11, 79-93.

HORNE, P. E. and TIMMONS, V. (2009) Making it work: teachers' perspectives on inclusion. International Journal of Inclusive Education, 13, 3, 273-286.

KUMPULAINEN, T. (ed.) (2014) Opettajat Suomessa 2013 [Teachers in Finland 2013]. Koulutuksen Seurantaraportit 2014:8. Helsinki: National Board of Education.

LARRIVEE, B. and COOK, L. (1979) Mainstreaming: a study of the variables affecting teacher attitude. The Journal of Special Education, 13, 3, 315-324.

MINKE, K. M., BEAR, G., DEEMER, S. A. and GRIFFIN, S. M. (1996) Teachers' experiences with inclusive classrooms: implications for special education reform. The Journal of Special Education, 30, 2, 152-186. 
MOBERG, S. (2003) Education for all in the North and the South: teachers' attitudes towards inclusive education in Finland and Zambia. Education and Training in Developmental Disabilities, 38, 4, 417-428.

NATIONAL ADVISORY BOARD ON RESEARCH ETHICS IN FINLAND (TENK) (2009) The Ethical Principles of Research in the Humanities and Social and Behavioural Sciences and Proposals for Ethical Review. Helsinki, Finland: TENK.

SCRUGGS, T. E. and MASTROPIERI., M. A. (1996) Teacher perceptions of mainstreaming/inclusion, 1958-1995: a research synthesis. Exceptional Children, $63,1,59-74$.

SRIVASTAVA, M., DE BOER, A. and VAN PIJL, S. (2015) Inclusive education in developing countries: a closer look at its implementation in the last 10 years. Educational Review, 67, 2, 179-195.

STATISTICS FINLAND (2018) Erityisopetus 2017 [Special Education 2017].

SUBBAN, P. and SHARMA, U. (2006) Primary school teachers' perceptions of inclusive education in Victoria, Australia. International Journal of Special Education, 21, 1, 42-52.

UNITED NATIONS (2006) Convention on the Rights of People with Disabilities. New York: United Nations.

UNITED NATIONS EDUCATIONAL, SCIENTIFIC, AND CULTURAL ORGANIZATION (UNESCO) (1994) The Salamanca Statement and Framework for Action on Special Needs Education. World Conference on Special Needs Education: Access and Quality. Salamanca, Spain, 7-10 June 1994 
YADA, A. and SAVOLAINEN, H. (2017) Japanese in-service teachers' attitudes toward inclusive education and self-efficacy for inclusive practices. Teaching and Teacher Education, 64, 222-229. 
Table 1. Classroom teachers $(\mathrm{N}=1,456)$ who agree or strongly agree with a statement.

\begin{tabular}{lccccc}
\hline SEN category & $\begin{array}{c}\text { Accepts } \\
\text { in own } \\
\text { class } \\
\%\end{array}$ & $\begin{array}{c}\text { Child } \\
\text { causes } \\
\text { extra work } \\
\%\end{array}$ & $\begin{array}{c}\text { Believes } \\
\text { will get } \\
\text { support }\end{array}$ & $\begin{array}{c}\text { Recommends } \\
\text { special class }\end{array}$ & $\begin{array}{c}\text { Has the } \\
\text { skills for } \\
\text { teaching } \\
\%\end{array}$ \\
\hline Learning disability & 76 & 83 & 27 & $\%$ & $\%$ \\
Immigrant student & 70 & 82 & 26 & 18 & 42 \\
ADHD & 59 & 93 & 20 & 43 & 59 \\
Severe CP & 33 & 65 & 59 & 70 & 6 \\
Severe ID & 22 & 74 & 55 & 86 & 5 \\
\hline
\end{tabular}

